\title{
Of Bailouts and Rescue Measures: Subsidies in Financial Services
}

Panagiotis Delimatsis

Abstract

As the recent financial crisis started unfolding, governments intervened through substantive subsidies and other benefits towards financial institutions to avoid their collapse. In addition, various stimulus packages were endorsed to rescue various sectors of the economy, including the financial sector, thereby creating possible distortions and unfair advantages for certain service suppliers. After a review of the measures taken which are dubious from a WTO perspective, this paper intends to examine the current legal discipline within the WTO and to assess the bite of the relevant legal provisions under the General Agreement on Trade in Services (GATS) absent any meaningful provisions relating to subsidies in the service sector. As financial reform at the domestic level takes shape, the time appears to be ripe for the conclusion of the negotiations on subsidies and safeguards within the GATS. In the meantime, close monitoring of the subsidized banks and the new players that emerged from mergers among financial institutions is required to ensure that no market distortions are maintained in the post-crisis landscape.

Research for this paper was funded by the Swiss National Science Foundation under a grant to the National Centre of Competence in Research on Trade Regulation, based at the World Trade Institute of the University of Bern, Switzerland. 


\title{
Of Bailouts and Rescue Measures: Subsidies in Financial Services
}

\author{
PANAgiotis DeLIMATSIS
}

\begin{abstract}
As the recent financial crisis started unfolding, governments intervened through substantive subsidies and other benefits towards financial institutions to avoid their collapse. In addition, various stimulus packages were endorsed to rescue various sectors of the economy, including the financial sector, thereby creating possible distortions and unfair advantages for certain service suppliers. After a review of the measures taken which are dubious from a WTO perspective, this paper intends to examine the current legal discipline within the WTO and to assess the bite of the relevant legal provisions under the General Agreement on Trade in Services (GATS) absent any meaningful provisions relating to subsidies in the service sector. As financial reform at the domestic level takes shape, the time appears to be ripe for the conclusion of the negotiations on subsidies and safeguards within the GATS. In the meantime, close monitoring of the subsidized banks and the new players that emerged from mergers among financial institutions is required to ensure that no market distortions are maintained in the post-crisis landscape.
\end{abstract}

\section{A. Introductory remarks}

The financial crisis of 2007-09, widely attributed to questionable subprime mortgage practices and the real estate bubble in the US, was the result of various deficiencies of the financial markets not only at the corporate level, but also at the supervision and regulation levels. ${ }^{1}$ This crisis was distinct from all previous crises due to four main reasons: first, an unprecedented use of complex financial instruments and socially dubious financial innovations; second, the interconnectedness of financial markets, both nationally and internationally, especially in developed economies; third, the high levels of leverage among financial institutions, notably non-banking ones; and, fourth, the key role of the household sector. ${ }^{2}$

\footnotetext{
* Associate Professor of Law and Co-Director, Tilburg Law and Economics Center (TILEC), Tilburg University, the Netherlands; and Senior Research Fellow, World Trade Institute, University of Bern, Switzerland. Financial support from the NCCR International Trade Regulation is gratefully acknowledged. This paper is based on developments and doctrine as of August 2011. Remaining errors are the author's alone. Contact: p.delimatsis@uvt.nl.

${ }^{1}$ See R. Lastra and G. Wood, 'The Crisis of 2007-09: Nature, Causes, and Reactions' (2010) 13:3 Journal of International Economic Law 531.

${ }^{2}$ See S. Claessens; G. Dell'Ariccia; D. Igan; and L. Laeven, 'Lessons and Policy Implications from the Global Financial Crisis’, IMF Working Paper WP/10/44, February 2010.
} 
The signs were already visible in summer 2007, when the investment bank Bear Stearns closed two of its hedge funds, which had reported large losses in the mortgage market, whereas BNP Paribas announced the end of activities for three hedge funds that specialized in US mortgage debt. Following the collapse of Lehman Brothers in autumn 2008, a fully-fledged global financial crisis started to unfold. While the market went into a tailspin, the unbearable distress in certain financial institutions, and the banking system overall, triggered a phenomenal intervention in financial markets by several governments around the world. Out of the fear that the financial sector would collapse, these governments intervened with massive subsidies or other help to save financial institutions. This intervention was made possible through deposit guarantees; tailor-made rescue packages, as was the case for the big American mortgage lenders Fannie Mae and Freddie Mac; or through actions that favoured and encouraged mergers, as was the case with Bear Stearns' takeover by JP Morgan Chase and Merrill Lynch's takeover by Bank of America. ${ }^{3}$ In the case of the Bank of America, a previous capital injection had also taken place. Such rescue packages and facilitated mergers can, however, accentuate the problem of systemic risk because they induce the creation of larger financial institutions.

In other cases, stimulus packages were endorsed, which were actually aimed at bringing changes to the financial sector as a whole. This was also because other subsectors of the financial sector were also suffering, the prime example being the American International Group (AIG), which the US government bailed out for US\$ 182 billion. ${ }^{4}$ It bears mention that this move indirectly saved several financial institutions, including Goldman Sachs, Morgan Stanley, and Bank of America, as well as several European banks, exposed to AIG derivatives.

The possibility that the measures taken distort trade flows and give a comparative advantage to the rescued institutions has been taken into account since the first meeting of G20 in Washington in November 2008. In London, the G20 Leaders committed to 'refrain from raising new barriers to investment or to trade in goods and services, imposing new restrictions, or implementing WTO inconsistent measures to stimulate exports' until the end of 2010, and to 'rectify promptly any such measure'. Furthermore, they pledged to 'minimize any negative impact on trade and investment of [their] domestic policy actions including fiscal policy and action in support of the financial sector'. The G20 also committed to notify any measures of this type promptly to the World Trade Organization (WTO), and called on the WTO, together with other international bodies, to monitor and report publicly on the adherence of

\footnotetext{
${ }^{3}$ To understand the perverse regulator-regulatee relationship, this merger was regarded as a 'shotgun wedding'. See The Financial Crisis Inquiry Commission, 'The Financial Crisis Inquiry Report', January 2011, pp. 382ff.

${ }^{4}$ With the exception of AIG, the insurance sector proved to be resilient to the crisis. By December 2009, only a few large US and EU insurers such as Aegon and ING in the Netherlands, and Hartford Financial Services in the US had sought government assistance to ensure their survival. Of the US\$ 1.7 trillion that financial institutions wrote down from the start of the crisis to early December 2009, insurers accounted for losses of US\$ 234 billion or $13.7 \%$ of the total, with AIG alone accounting for US\$ 98 billion of these losses. Thus, more than $80 \%$ of the losses in the insurance sector were concentrated in the US. See WTO, 'Financial Services', Background Note by the Secretariat, S/C/W/312, 3 February 2010, p. 29.
} 
G20 members to their undertakings on a quarterly basis. Similar statements were made in Pittsburgh in September 2009. The fact remains that several of these measures are dubious from a WTO law perspective, notably as far as their consistency with the nondiscrimination principle is concerned. ${ }^{5}$ Even so, it may prove impossible to substantiate a complaint not only due to the deficiencies of the WTO rules, but also because of the temporal character of the measures and the prospective nature of remedies in the WTO.

The structure of this paper is as follows: after a succinct overview in Section B of the rescue measures in the financial sector during the crisis, Section $C$ discusses the legal discipline relating to subsidies in the WTO Agreement on Subsidies and Countervailing Measures (SCM Agreement). As the rules of the SCM Agreement only apply to goods, Section D examines the relevant provisions under the General Agreement on Trade in Services (GATS). Although the GATS lacks a comprehensive mechanism for regulating subsidies in the service sector, an examination of the other GATS rules that rescue measures and bailouts will have to comply with is made. Section E concludes.

\section{B. Saving the Financial System, Restoring Confidence - An Overview of the Measures Adopted}

After the dramatic bankruptcy of Lehman Brothers in 2008, which, for the record, is the largest bankruptcy to be filed in the history of the US (US\$ 639 billion), the EU and the US saved their financial systems through massive state aid, with equity participation and debt support for the financial sector. ${ }^{6}$ Assistance to the financial sector had two distinctive features: it either reduced the borrowing costs of the financial institutions or boosted the net worth of these institutions. ${ }^{7}$ The US Troubled Asset Relief Programme (TARP), which formed the operational part of the Emergency Economic Stabilization Act of 2008, authorized the Treasury to use some US\$ 700 billion to stabilize financial markets. ${ }^{8}$ Several other short-term credit and liquidity facilities allowed financial institutions to make it through the critical period. In the UK, a bank rescue programme worth some $£ 500$ billion was announced in autumn 2008 for the same reason, but this one focused on the purchase of shares in the threatened banks. In Germany, it is estimated that from 2008-2010 the government, through the Sonderfonds für Finanzmarktstabilisierung (SoFFin) provided about $€ 454$ billion to banks. In 2009 alone, €212 billion were given as guarantees on bank liabilities, $€ 40$ billion as capital injections and $€ 10$ billion for the relief of impaired assets. The European Commission estimated that in the period 2008-2009 the

\footnotetext{
${ }^{5}$ OECD; WTO; UNCTAD, 'Report on G20 Trade and Investment Measures: September 2009 to February 2010', March 2010.

${ }^{6}$ See Bank for International Settlements (BIS), 79th Annual Report: 1 April 2008-31 March 2009, Chapter VI, 29 June 2009, pp. 91ff.

${ }^{7}$ Cf. E. Farhi and J. Tirole, 'Collective Moral Hazard, Maturity Mismatch, and Systemic Bailouts', 8 February 2011.

${ }^{8}$ The entire amount was never used. The amount finally spent was used not only in the financial sector, but also in other areas such as the autmotive industry.
} 
assistance that EU Member States provided to the financial sector exceeded $€ 2$ trillion, the bulk of which consisted of guarantees on bank liabilities. The advantage of such guarantees is that they do not weigh heavily on the public finances when compared to other measures such as recapitalizations.

Central banks have provided massive liquidity to the financial system, and have bought securities directly in the market. As 'lenders of last resort', central banks have been a source of liquidity support to financial institutions, typically through loans extended against collateral. Central banks also used monetary policy to assist in the stabilization of the markets: in an unprecedented move, seven central banks agreed to cut interest rates in October 2008 (England, US, China, Switzerland, Canada, Sweden and the European Central Bank).

In addition, in the US, a paradigm shift occurred, as two large investment banks, Goldman Sachs and Morgan Stanley, applied to become traditional bank holding companies. The US Federal Reserve approved the application, thereby giving these institutions the opportunity to benefit from the rescue packages and other emergency schemes. Thus, in the space of a few months, all major investment banks in the form we knew them disappeared. ${ }^{9}$ This was mainly due to the failure of the US Securities and Exchange Commission (SEC) to restrict their risky activities or to require the availability of adequate capital and liquidity buffers. ${ }^{10}$

More specifically, policies to help financial institutions weather the shock included: ${ }^{11}$

- liquidity provision through collateralized lending and other schemes or schemes that allowed for separation of good assets from bad assets, placing the latter off the balance sheets of banks;

- support for short-term wholesale funding markets;

- more generous guarantees on retail deposits (by increasing the threshold on savings eligible for deposit insurance), loans (including guarantees on interbank loans or on banks' issues of debt) and other liabilities, either targeting specific institutions or the whole sector. Later, in light of the continuing recession, governments also started to offer general loan guarantees, which would also improve access of firms to investment and working capital loans. Such instruments give an advantage to the final beneficiary (eg companies) because they avoid higher costs due to fees and/or interest rates, which they would otherwise have to pay. ${ }^{12}$

- purchases or exchanges of non-performing or illiquid assets. For instance, the

\footnotetext{
${ }^{9}$ Taking Goldman Sachs' behaviour as a case-study, a recent US Senate Report found that investment banks that engineered, sold, traded, and profited from mortgage related structured finance products were a major cause of the financial crisis. Thus, with the benefit of hindsight,the high-risk high-return culture that these banks nurtured all these years has clearly failed. See US Senate, Permanent Committee on Investigations, 'Wall Street and the Financial Crisis: Anatomy of a Financial Collapse', 13 April 2011, pp. 318ff.

${ }^{10}$ See The Financial Crisis Inquiry Commission, above note 3, p. 155.

${ }^{11}$ Claessens et al, above note 2 .

${ }^{12}$ See WTO, above note 4, p. 31.
} 
Swiss National Bank (SNB) bought mortgage-related assets from UBS and put them in a special investment vehicle, thereby reducing the risk-weighted assets of the bank and thus the regulatory capital that it had to hold against potential losses. ${ }^{13}$ These were one-off measures; and

- capital injections to banks (for instance, through purchase of shares) or governmental support for takeovers of failing banks by better capitalized banks. Governments opted for the recapitalization of those institutions that were insolvent. The UK Treasury sought to acquire common stock, whereas most governments decided to buy hybrid securities which offered a combination of a stable income stream through bonds and the potential appreciation of common stock. These were also one-off measures. A significant portion of the amounts involved were repaid to the governments that initially disbursed them.

As the Table 1 shows, all major economies have taken more than one measures of this type to stabilize their financial market.

Table 1

\begin{tabular}{|c|c|c|c|c|c|c|c|c|c|c|c|c|c|}
\hline \multicolumn{14}{|c|}{ Special measures to stabilise the financial system ${ }^{1}$} \\
\hline & $\mathrm{AU}$ & BR & CA & $\mathrm{CH}$ & $\mathrm{DE}$ & FR & GB & HK & IT & $\mathrm{JP}$ & KR & NL & US \\
\hline Deposit insurance & $\checkmark$ & & & $\checkmark$ & $\checkmark$ & & $\checkmark$ & $\checkmark$ & $\checkmark$ & & $\checkmark$ & & $\checkmark$ \\
\hline $\begin{array}{l}\text { Restriction on short } \\
\text { selling }\end{array}$ & $\checkmark$ & & $\checkmark$ & & $\checkmark$ & $\checkmark$ & $\checkmark$ & & $\checkmark$ & $\checkmark$ & & $\checkmark$ & $\checkmark$ \\
\hline Capital injections & & $\checkmark$ & & $\checkmark$ & $\checkmark$ & $\checkmark$ & $\checkmark$ & $\checkmark$ & $\checkmark$ & $\checkmark$ & $\checkmark$ & $\checkmark$ & $\checkmark$ \\
\hline Debt guarantees & $\checkmark$ & & $\checkmark$ & & $\checkmark$ & $\sqrt{2}$ & $\checkmark$ & & $\checkmark$ & $\checkmark$ & $\checkmark$ & $\checkmark$ & $\checkmark$ \\
\hline Asset insurance & & & & & & & $\checkmark$ & & & & & $\checkmark$ & $\checkmark$ \\
\hline Asset purchases & $\checkmark$ & & $\checkmark$ & $\checkmark$ & $\checkmark$ & & $\checkmark$ & & & $\checkmark$ & & & $\checkmark$ \\
\hline Nationalisation & & & & & $\checkmark$ & & $\checkmark$ & & & & & $\checkmark$ & $\checkmark$ \\
\hline
\end{tabular}

Source: BIS (2009) $)^{14}$

It bears noting that, depending on the circumstances, governments have combined the abovementioned measures or offered such options to the financial institutions at different times as the crisis was unfolding. In some cases, nationalization of financial institutions has taken place with a view to restructuring them. For instance, the UK government decided to nationalize Northern Rock in the wake of fears about its solvency and an unprecedented bank run. Later on, the UK government opted for the restructuring of the bank with the creation of a new company dealing with banking (Northern Rock plc) and one focusing on asset management (Northern Rock (Asset

\footnotetext{
${ }^{13}$ See L. Thévenoz, 'The Rescue of UBS', in M. Giovanoli and D. Devos (eds), International Monetary and Financial Law - The Global Crisis (Oxford University Press, 2010), p. 378.

${ }^{14}$ See BIS, above note 6, p. 103.
} 
Management) plc). The latter would retain the balance of Northern Rock's mortgage book, ie the impaired assets.

In other cases, and in order to avoid being accused of nationalization, the competent authorities sought to have non-voting stock. For instance, part of the TARP in the US (US\$ 250 billion) was used to purchase equity in nine financial institutions. This capital injection was accompanied by strict requirements relating to executive compensation and corporate governance, while giving incentives to the institutions to pay the government back - which, in the overwhelming majority of cases, did happen. ${ }^{15}$ However, limiting executive pay was a daunting task and various payments of this type were actually made, to the great disappointment of governments - and taxpayers.

There have also been cases where the available facilities were not used. ${ }^{16}$ For instance, Italy's programme to offer debt guaranteed for domestically incorporated banks or Hong Kong's contingent bank capital facility and expanded discount window facilities. Other programmes expired without having any impact on the markets, whereas other support measures became permanent, the prime example being the increase of minimum deposit insurance after a coordinated effort within the EU.

It had been noted that the introduction of the abovementioned measures in an uncoordinated manner could leave room for arbitrage between countries. Aware of this problem, several countries decided to take coordinated action to increase deposit insurance. This was also the case in the EU, where a gradual increase of the minimum deposit insurance across the EU was agreed upon. The same applies with equal force in the case of exit strategies. Indeed, the possibility of financial and regulatory arbitrage across jurisdictions makes coordination among countries necessary. This relates most notably to government bank debt guarantees. More generally, in countries and areas which are particularly interdependent (the EU or South Asia), it appears that regulators and policymakers were especially concerned with levelling the playing field when measures to re-establish financial stability were taken. This concern may not be relevant for certain measures, such as the purchase of 'bad' assets by governments. Such 'bad' assets may hamper the solvency of a given government and thus have a negative impact on sovereign debt, but their impact on the market is negligible. Again, this will depend on the assets, because under certain circumstances, freeing a given company from its 'bad' assets can still infringe rules relating to subsidization or state aid. ${ }^{17}$

Although it was not at the source of the financial crisis, the EU felt its effects strongly. It was estimated that the crisis-related losses incurred by European credit institutions

\footnotetext{
${ }^{15}$ See The Financial Crisis Inquiry Commission, above note 3, p. 374.

${ }^{16}$ See FSB, 'Exit from extraordinary financial sector support measures - Note for G20 Ministers and Governors meeting 6-7 November 2009', 7 November 2009.

${ }^{17}$ State aid is a broader concept than a subsidy, as the former embraces not only positive benefits, such as subsidies themselves, but also interventions which are normally included in the budget of an undertaking and which, without therefore being subsidies in the strict meaning of the word, are similar in character and have the same effect..ECJ Case 30/59, Steenkolenmijnen v High Authority [1961] ECR 3,19 .
} 
amounted to some $€ 1$ trillion or 8\% of the EU GDP in the period 2007-2010. In an effort to allow the EU Member States to save their financial institutions during the financial upheaval, the European Commission attempted to proactively set the conditions for rescues, while reminding the EU Member States that such measures can only be justified if they are temporary and as long as the exceptional circumstances continue to prevail. This was yet another reassurance for the Member States that the Commission was willing to bend the otherwise stringent EU state aid rules enshrined in Article 107 of the Treaty on the Functioning of the European Union (TFEU). ${ }^{18}$ However, the goal is still that the ordinary state aid rules will apply again as of 1 January 2012. ${ }^{19}$ The current sovereign debt crisis in several Member States may lead to a postponement of this deadline. Through the coordinated scrutiny of rescue packages adopted by the EU Member States, the EU managed to alleviate concerns about competitive distortions, at least in the EU internal market. Similar examinations do not seem to have taken place in the US.

It is worth noting that the powers that the Commission has under the EU state aid rules are unparalleled when compared to those of other international organizations. ${ }^{20}$ It is the Commission that developed the general policy in this area and its decisions are subject to a marginal judicial review from the EU Courts. The Court of Justice of the European Union has repeatedly argued that it is not for the EU judiciary to substitute its economic assessment for that of the Commission. ${ }^{21}$ Thus, review is limited to the examination of the compliance of the Commission with procedural rules, such as the giving-reasons requirement. The courts will also assess whether the facts were materially accurate and whether a manifest error of assessment of a decision ultra vires has taken place. $^{22}$

The Commission issues various Communications covering the entire palette of measures taken, thereby harmonizing the criteria under which state support to financial institutions during the financial crisis could be EU-consistent. ${ }^{23}$ The first three

\footnotetext{
${ }^{18}$ Art. 107:1 TFEU provides:

Save as otherwise provided in the Treaties, any aid granted by a Member State or through State resources in any form whatsoever which distorts or threatens to distort competition by favouring certain undertakings or the production of certain goods shall, in so far as it affects trade between Member States, be incompatible with the internal market.
}

However, pursuant to Art. 107:3(b) any 'aid to promote the execution of an important project of common European interest or to remedy a serious disturbance in the economy of a Member State' may be considered to be compatible with the internal market.

${ }^{19}$ See P. Marsden and I. Kokkoris, 'The Role of Competition and State Aid Policy in Financial and Monetary Law’ (2010) 13:3 Journal of International Economic Law 875, at 884.

${ }^{20}$ See also L. Hancher; P.J. Ottervanger and P.J. Slot, EC State Aids, 3rd edition (Sweet and Maxwell, 2006).

${ }^{21}$ See T-149/95, Ducros v Commission [1997] ECR II-2031, para. 63.

22 See T-228 and 233/99, Westdeutsche Landesbank Girozentrale and another v Commission [2005] ECR II-2123, para. 97.

${ }^{23}$ In addition, a temporary framework was adopted to provide Member States with the possibility to adopt additional State aid measures aimed at facilitating the access of companies to finance. However, this did not prevent a sharp decrease in output. See Communication from the Commission, Temporary Community framework for State aid measures to support access to finance in the current financial and economic crisis, [2009] OJ C 16/1. As the crisis subsided, the temporary framework was amended, with the most recent amendment being incorporated into the Commission's Communication 'Temporary 
Communications establish the requirements for the compatibility of the main types of assistance granted by Member States, that is, guarantees on liabilities, recapitalizations and asset relief measures. ${ }^{24}$ In a later Communication, the so-called 'Restructuring Communication' the Commission set out the specific features that a restructuring or viability plan must have in all cases of crisis-related state aid granted to financial institutions within the meaning of Article 107:3(b) TFEU. The Communication applied to aid that was notified until end-2010. ${ }^{25}$ This was prolonged until the end of 2011 by the so-called 'Exit Communication', ${ }^{26}$ obliging those banks which have recourse to state support in the form of capital or impaired asset measures to submit a restructuring plan.

Of course, this is not the first time that the Commission has issued guidelines dealing with the appropriate methods to rescue a company. On the contrary, it has provided advice on how a company should be restructured, rescued or assisted in dealing with its operating costs before. ${ }^{27}$ Like the recent Communications, these guidelines require that: viability be restored; aid be proportional to the restructuring costs and benefits; undue distortions of competition be avoided; and that the restructuring plan is fully implemented. Before the crisis, the Commission also adopted the revised Rescue and Restructuring Guidelines of $2004^{28}$ which can, under certain conditions, allow subsidization of certain undertakings in difficulties in a manner that is compatible with Article 107:3(c) TFEU. These guidelines drew a clear line between rescue aid and restructuring aid. The former is temporary assistance (for no more than six months) to keep a distressed undertaking afloat until a restructuring and/or liquidation plan is implemented. The latter is typically a feasible and comprehensive plan to restore the long-term viability of an undertaking. At the beginning of the crisis, the Commission examined several cases under these Guidelines: for instance, the decision relating to the German bank Hypo Real Estate, ${ }^{29}$ the decision relating to the rescue aid package

\footnotetext{
Union framework for State aid measures to support access to finance in the current financial and economic crisis' [2011] OJ C 6/5. This recent amendment prolongs the granting of aid until the end of 2011. In the US, the American Recovery and Reinvestment Act of 2009 set up the largest US fiscal stimulus package, with an estimated cost of US\$ 787 billion in the period 2009-19.

${ }^{24}$ Communication on the application of State aid rules to measures taken in relation to financial institutions in the context of the current global financial crisis (the Banking Communication), [2008] OJ C 270/8; Communication on the recapitalisation of financial institutions in the current financial crisis: limitation of aid to the minimum necessary and safeguards against undue distortions of competition (The Recapitalization Communication), [2009] OJ C 10/2; Communication from the Commission on the treatment of impaired assets in the Community banking sector (the Impaired Assets Communication), [2009] OJ C 72/1.

${ }^{25}$ Communication of the return to viability and the assessment of restructuring measures in the financial sector in the current crisis under the State aid rules (the Restructuring Communication), [2009] OJ C 195/9. For a decision by the Commission based on this Communication, see Case N546/2009, Restructuring of Bank of Ireland [2011] OJ C 40/9.

${ }^{26}$ Communication on the application, after 1 January 2011, of State aid rules to support measures in favour of banks in the context of the financial crisis, [2010] OJ C 329/7.

${ }^{27}$ Guidelines on State Aid for Rescuing and Restructuring Firms in Difficulty [1999] OJ C 288/2.

${ }^{28}$ Community Guidelines on State Aid for Rescuing and Restructuring of Firms in Difficulty [2004] OJ C 244/2.

${ }^{29}$ Case NN 44/2008, [2008] OJ C 293/1.
} 
for the UK mortgage bank Bradford \& Bingley, ${ }^{30}$ or even the first decision on the Northern Rock saga. ${ }^{31}$

In the period 2008-11, the European Commission examined a series of measures taken by various Member States. ${ }^{32}$ Typically, the entire state aid edifice within the EU rests upon the principle of ex ante authorization. This means that a given state can grant state aid only once the measure has been notified to and approved by the Commission. ${ }^{33}$ However, owing to the need for a rapid reaction by the Commission, the Banking Communication ${ }^{34}$ allowed for expedited decisions upon notification, sometimes within days. ${ }^{35}$ In the Banking Communication, the Commission clarified that Article 107:3(b) TFEU ${ }^{36}$ should be used as a legal basis for rescue measures aimed at addressing the crisis and restoring market confidence in the financial sector. ${ }^{37}$ The Commission, however, emphasized that this would not affect its practice of interpreting narrowly what would constitute a 'serious disturbance' in the economy of a Member State. ${ }^{38}$ This is in accordance with previous case law whereby the Court of Justice of the European Union found that three elements are noteworthy in Article 107:2(b) TFEU: first, that the disturbance at stake must affect the whole of the economy of the Member State concerned and not merely a region thereof; second, that, the complex assessments of an economic and social nature related to the term 'serious disturbance' fall within the exercise of the wide discretion that the Commission enjoys; and, third, that, being a derogating provision, Article 107:2(b) needs to be interpreted strictly. ${ }^{39}$

In the Banking Communication, the Commission's objective was to give guidance on measures designed to ensure the stability of national financial systems rather than the stabilization of individual banks. Whereas swift responses were pledged, the Commission also warned that the measures taken to address the crisis cannot generate unnecessary distortions of competition between financial institutions operating in the market or negative spillover effects on other competitors, other sectors and other Member States. Competitive distortions can arise when only some of the financial

\footnotetext{
${ }^{30}$ Case NN41/2008, [2008] OJ C 290/2.

${ }^{31}$ Case NN 70/2007, [2008] OJ C 43/1.

32 For the list of cases according to country see: http://europa.eu/rapid/pressReleasesAction.do?reference=MEMO/11/325\&format=HTML\&aged=0\&la nguage $=$ EN\&guiLanguage $=$ en.

${ }^{33}$ Cf. L. Hancher, 'Bailouts in the Financial Sector: The Compatibility with the EU State Aid Rules' in P. Delimatsis and N. Herger (eds), Financial Regulation at the Crossroads - Implications for Supervision, Institutional Design and Trade (Kluwer Law International, 2011), p. 123, at 128.

${ }^{34}$ See above note 24.

35 This was, for instance, the case with the rescue aid given by the British government to Bradford and Bingley. See Case NN41/2008, [2008] OJ 290/2.

${ }^{36}$ See above note 18 .

${ }^{37}$ Typically, in its decisions, the Commission would find the existence of state aid based on the market economy investor principle (MEIP), but would consider the measure as justified under Art. 107:3(b) TFEU.

${ }^{38}$ For this practice, see Commission Decision in Case NN 70/07 Northern Rock [2008] OJ C 43/ 1, Commission Decision in Case NN 25/08 Rescue aid to WestLB, [2008] OJ C 189/3, Commission Decision in Case C 9/08, SachsenLB [2009] OJ L 104/34.

${ }^{39}$ See C-57 and 61/00, Freistaat Sachsen and others v Commission [2003] ECR I-9975, paras 167, 169.
} 
institutions (eg the domestic ones) benefit from bailout measures to the detriment of the other (eg foreign) institutions. Such distortions can be generated when, for example, bailout measures affect banking flows between markets, thereby worsening the problems of liquidity or causing additional distress to specific financial institutions. This also goes for guarantee schemes, often of unlimited levels, which were established to mitigate risk. ${ }^{40}$ Therefore, objective and pre-established eligibility criteria are essential. $^{41}$

Thus, the principle of non-discrimination has to be respected in that all institutions, including subsidiaries, incorporated in a Member State that adopts a guarantee scheme and with significant activities in that Member State should benefit from the scheme. In any case, the guarantee schemes chosen should be reviewed every six months (the results of the reviews should be sent to the Commission) and cannot, in principle, last longer than two years. Importantly, the Commission requires that the beneficiaries from such schemes pay adequate fees back to the State for the guarantees. Member States could - and did - consider including in the schemes a claw-back or 'better fortunes' clause which would require that the beneficiaries pay either the fee for the guarantee or reimburse at least part of any amounts paid by the Member State under the guarantee once they are in a position to do so.

The Banking Communication set similar conditions with respect to recapitalization schemes for fundamentally sound banks, notably underlining the temporal and urgent character of the measures and the need for adequate safeguards against abuses and undue competitive distortions. These were further refined in the Recapitalization Communication, which authorized recapitalization (for both sound banks and banks and banks facing insolvency) through acquisition of ordinary or preferred stock by governments, provided that market-oriented remuneration rates, adequate behavioural safeguards and continuous review were introduced. Finally, the Banking Communication refers to the possibility of a controlled winding up of certain financial institutions either after a failed rescue aid or as part of a general guarantee scheme. In enforcing liquidation measures, the Member States are required to minimize moral hazard, for instance, by excluding shareholders and other categories of creditors from getting the benefit of any aid during the procedure of a controlled winding-up.

In the period between October 2008 and October 2010, the Commission took more than 200 decisions relating to state aid measures in the financial sector. These decisions authorized, amended and, in certain cases, extended more than 40 schemes or addressed the situation of more than 40 financial institutions in 22 Member States. ${ }^{42}$ Only in a handful of cases, did the Commission adopt conditional decisions after a formal investigation procedure. The measures approved by the Commission in this

\footnotetext{
${ }^{40}$ See also WTO, Trade Policy Review Body, 'Report on the TPRB from the Director-General on the Financial and Economic Crisis and Trade-Related Developments', WT/TPR/OV/W/2, 15 July 2009, para. 78.

${ }^{41}$ See for instance, the Commission's decision on the guarantee scheme for Irish banks. See Case NN48/2008, Banks in Ireland, [2008] OJ C 312/2.

${ }^{42}$ See European Commission, 'State Aid Scoreboard - Autumn 2010 Update', COM(2010) 701 final, 1 December 2010, p. 8.
} 
period amounted to over $€ 4.5$ trillion, ${ }^{43}$ about $80 \%$ of which was in the form of guarantees. ${ }^{44}$ In addition, since the adoption of the Restructuring Communication in July 2009, the Commission has approved the restructuring of several financial institutions in the EU. An interesting case, especially given its cross-border dimension, was the approval of the aid granted by Belgium, France and Luxembourg for the restructuring of Dexia. ${ }^{45}$ All three countries saved Dexia through various measures including capital injections and emergency liquidity support. ${ }^{46}$ Like in other cases of restructuring, one of the consequences for the financial institution at issue is the shrinking of the areas in which it can be active. In Dexia's case, it had to abandon proprietary trading and reduce its public-sector lending activity outside the three Member States. According to the Commission, the long-term viability of the bank could only be ensured through the reduction of its dependence on the money and bond markets.

To sum up, all the above-mentioned policies, even if sometimes unduly burdensome for the taxpayers, did succeed in their objective of avoiding widespread bank failures. ${ }^{47}$ Overall, the monetary and fiscal stimulus programmes that several WTO Members adopted after mid-2008 were successful in reversing the decrease of global trade and output that the financial crisis brought about. Trade volume in developing countries had returned to its pre-crisis levels by mid-2010 and global trade by end2010. ${ }^{48}$ However, the recovery is fragile. The current sovereign debt crisis does not leave room for any optimism in the short run. Indeed, bailouts for countries such as Greece or Ireland that replace the bailouts for private companies such as Northern Rock can be equally worrisome. Another concern relates to the current size of banks in the post-crisis environment. It seems that some banks, instead of using the money to increase lending, preferred to keep the funds that the governments put at their disposal to improve their balance sheets. According to certain estimates, the biggest US banks are $20 \%$ larger than they were before the financial crisis. ${ }^{49}$

\section{The Regulation of Subsidies in the SCM}

Basic economics suggests that, depending on the kind of externality that a government has to cope with, a variety of interventionist measures are available. In the case of a

\footnotetext{
${ }^{43}$ It is worth noting that the amount of public support actually used is much lower. For instance, in the period 2008-09 it was €2 trillion.

44 See Commission Staff Working Paper accompanying the report from the Commission on Competition Policy 2010, COM(2011) 328 final, 10 June 2011, p. 8.

${ }^{45}$ Case C9/2010, Restructuring of Dexia [2010] OJ L 274/54.

${ }^{46}$ Some of these measures had already been approved by the Commission in an earlier temporary rescue in November 2008.

${ }^{47}$ Cf. M. King, 'Time to buy or just buying time? The market reaction to bank rescue packages', BIS Working Papers No. 288, September 2009.

${ }^{48}$ See WTO, TPRB, 'Symposium: The Financial and Economic Crisis and the Role of the WTO', Background Note by the Secretariat, WT/TPR/OV/W/4, 14 June 2011, p. 2. See also OECD; WTO; UNCTAD, 'Report on G20 Trade and Investment Measures (Mid-October 2010 to April 2011)', May 2011, p. 7.

${ }^{49}$ N. Barofsky, 'Where the Bailout Went Wrong', New York Times, 29 March 2011.
} 
negative production externality (that is, a production process that has detrimental external effects on others, eg environmental pollution) the optimal intervention would entail a Pigouvian tax on production equal to the damage. ${ }^{50}$ If instead the consumers create the negative externality, then a tax on consumption will be called for as the optimal policy. ${ }^{51}$ If, however, the externality were positive (eg the inability of an innovative firm to appropriate fully the knowledge and subsequently the technological spillovers it generates), ${ }^{52}$ the optimal intervention would be a subsidy and not a tax. ${ }^{53}$ Public goods such as parks, roads, or even clean air, lighthouse services, commercialfree TV and radio broadcasts, are all examples of positive externalities. The final aim of the governmental intervention is to instigate the full 'internalization' of the externality and thereby correct the distortion without creating a new one. Thus, one of the most important contributions of the theory of domestic distortions (or theory of optimum subsidy) is the so-called 'targeting principle'. This is a powerful tool that allows a practical welfare-ranking of policies from first-best to $n$ th-best when it comes to any market failure or non-economic objective. ${ }^{54}$

The previous observations show that subsidization is not necessarily an inefficient public policy instrument. In addition, subsidization can be used for strategic reasons in imperfectly competitive markets to the benefit of domestic firms. ${ }^{55}$ This said, subsidization can also undermine commitments undertaken and thus market access expectations. Furthermore, subsidies directed towards increased exports may lead to a misallocation of resources and outputs between foreign and domestic markets, thereby giving an artificial comparative advantage to domestic producers active in global markets. $^{56}$

\footnotetext{
${ }^{50}$ Alternatively, and in the absence of transaction costs, the two parties could find a satisfactory solution, eg through payments to outweigh the environmental harm that the other party experiences. See R. Coase, 'The Problem of Social Cost' (1960) 3 Journal of Law and Economics 1.

${ }^{51}$ AC Pigou, The Economics of Welfare, $4^{\text {th }}$ edition (MacMillan, 1962). Unlike most taxes, which are inefficient because they result in a deadweight loss, Pigouvian taxes, such as on alcohol or cigarettes, improve overall economic efficiency. The Pigouvian approach will not always be sufficient, since it fails to consider that in a single externality relationship there are always two parties involved. Thus, there is a reciprocal bargain that mustbe made. As Coase pointed out, whenever transaction costs (ie all the costs necessary to carry out a market transaction) are low and property rights well-defined, people will make voluntary exchanges for mutual benefits. Thus, a government intervention may not be necessary in order to correct the market failure associated with the externality. R. Coase, 'The Problem of Social Cost' (1960) 3 Journal of Law and Economics 1.

${ }^{52}$ P Krugman, 'Is Free Trade Passé?’ (1987) 1(2) The Journal of Economic Perspectives 137.

${ }^{53}$ A. Deardorff, 'The Economics of Government Market Intervention, and Its International Dimension' in M. Bronckers and R. Quick (eds), New Directions in International Economic Law: Essays in Honour of J. H. Jackson (Kluwer Law International, 2000), at 75.

${ }^{54}$ D Rodrik, 'Policy Targeting with Endogenous Distortions: Theory of Optimum Subsidy Revisited' (1987) 102(4) The Quarterly Journal of Economics 903; also J Bhagwati and VK Ramaswami, 'Domestic Distortions, Tariffs and the Theory of Optimum Subsidy' (1963) 71(1) The Journal of Political Economy 45; and J Bhagwati, 'The Generalized Theory of Domestic Distortions and Welfare' in J. Bhagwati; R. Mundell; R. Jones; and J. Vanek (eds), Trade, Balance of Payments and Growth: Essays in Honor of Charles P. Kindleberger (North-Holland Publishing, 1971), 71.

${ }^{55}$ See. J. Brander and B. Spencer, 'Tariffs and the Extraction of Foreign Monopoly Rents under Pontential Entry' (1981) 14:3 The Canadian Journal of Economics 371; and J. Brander and B. Spencer, 'Export Subsidies and International Market Share Rivalry' (1985) 18 Journal of International Economics 83.

${ }^{56}$ See also WTO, World Trade Report 2006 - Exploring the links between subsidies, trade and the
} 
When viewed from a trade law perspective, several of the abovementioned rescue measures could constitute subsidization and can have a distortive impact on competitive conditions in financial markets at the national and international level, notably when there is room for arbitrage, as noted above, or when 'cheap' capital in the form of capital injection enhances the capital base of a financial institution. It has been estimated that border measures and domestic measures such as subsidies and bailouts account for about half of a total, annual trade-distortive effect of between $0.25 \%$ (US\$ 35 billion) and $0.75 \%$ (US\$ 110 billion) of world trade. ${ }^{57}$ Nevertheless, various emergency measures and unwinding of assets and liabilities were not discriminatory, at least not overtly. For instance, the British Bradford \& Bingley was sold to the Spanish Santander, whereas the UK's plans to sell Northern Rock will be conducted through an international bid process.

The WTO has a fairly powerful system for disciplining subsidies, notably the ones contingent on export performance. However, it lacks a comprehensive framework to regulate subsidies in services. This would mean that, in principle, more than $80 \%$ of the approximately US\$ 12 trillion of US federal crisis relief escapes the WTO's purview. ${ }^{58}$ In this section, we discuss the legal disciplines with regard to subsidies in goods, whereas in the next section the legal framework relating to subsidies in the service sector is examined.

Pursuant to Article 1 SCM, there are three cumulative elements that have to be met to substantiate the existence of subsidy:

- First, financial contribution by a government or public body, or an income or price support. This can be a direct transfer of funds or an omission to collect revenue which is otherwise due. Private entities delegated by their government to act on its behalf can also come within the ratione personae scope of the provision (anti-circumvention provision). ${ }^{59}$

- $\quad$ Second, benefit conferred to the recipient. The market or the private investor is used as the yardstick to determine the existence and amount of the advantage. ${ }^{60}$ For instance, a government loan confers a benefit to a given company when a comparable commercial loan would cost the company more. In assessing the benefit, the WTO judiciary will have to 'examine the terms and conditions of a loan at the time it is made and compare them to the terms and conditions that would have been offered by the market at that time. ${ }^{, 61}$

\footnotetext{
WTO, 2006, p. 55.

${ }^{57}$ See WTO, TPRB, above note 48, p. 30. See also C. Henn and B. McDonald, 'Protectionist Responses to the Crisis: Damage Observed in Product-Level Trade', IMF Working Paper WP/11/139, June 2011.

${ }^{58}$ See G. Horlick and P. Clarke, 'WTO Subsidy Disciplines During and After the Crisis' (2010) 13:3 Journal of International Economic Law 859, at 860.

${ }^{59}$ See Appellate Body Report, US - Countervailing Duty Investigation on DRAMS, WT/DS296/AB/R, para. 116.

${ }^{60}$ In the EU, a market economy investor test is applied to determine if state aid exists. See C-482/99, France $v$ Commission (Stardust Marine), [2002] ECR I-4397, paras 69ff.

${ }^{61}$ Appellate Body Report, EC and certain Member States - Large Civil Aircraft, judgment of 18 May 2011, WT/DS316/AB/R, para. 838.
} 
- Third, a subsidy should be specific, with the most obvious case being when the granting authority limits a given advantage to specific recipients. This can be a single enterprise or industry or a class of enterprises or industries that are known and particularized. ${ }^{62}$ A subsidy can also be de facto specific, whereas it will be regarded as non-specific when eligibility is automatic and access to the subsidy is limited through objective and neutral criteria provided that they are strictly adhered to. Such criteria should not favour certain companies, but should rather be horizontal in application, such as number of employees or size of company.

Domestic subsidies are not prohibited, but are actionable according to the SCM Agreement if they cause adverse effects within the meaning of Article 5 SCM. It is for the complaining party to adduce evidence demonstrating that the subsidy has such effects by either causing injury to its domestic industry; nullification or impairment of benefits accruing to the complaining party; or by causing serious prejudice to the complaining party's interests. ${ }^{63}$ In other words, serious prejudice allows an affected WTO Member to file a complaint against a subsidy if it causes substantial damage to the Member's export opportunities worldwide. ${ }^{64}$ The responding party can justify its measures by proving that the subsidy did not produce any adverse effect of the kind described under Article 6.3 SCM, such as displacement or impediment of exports resulting from subsidized sales, significant price undercutting, price suppression or depression. ${ }^{65}$ If one of these effects is ultimately established, the subsidizing Member will have to either withdraw the subsidy or remove the adverse effects.

The only domestic subsidies that the SCM outlaws are subsidies conditioned upon local content requirements. Furthermore, the previously non-actionable subsidies granted for purposes of environmental protection, to compensate for regional inequalities in the territory of a WTO Member, or for the promotion of research and development (R\&D) have expired and thus WTO Members can no longer derogate from the rules laid down in the SCM. In addition, Article III:8(b) GATT exempts domestic subsidies from the national treatment discipline. On the other hand, according to Article 3 SCM, both de jure ${ }^{66}$ and de facto export subsidies are per se prohibited (except for agriculture). However, subsidies to export-oriented producers which are not contingent on export performance are regarded as actionable production subsidies. In turn, import substitution subsidies, that is, subsidies contingent upon the use of domestic over imported goods, are also per se prohibited.

\footnotetext{
${ }^{62}$ Appellate Body Report, US - Anti-Dumping and Countervailing Duties (China), paras 366 and 373.

${ }^{63}$ See Art. 5 SCM.

${ }^{64}$ Cf. A. Sykes, 'The Questionable Case for Subsidies Regulation: A Comparative Perspective' Stanford Law and Economics Research Paper No 380, 2009, p. 9.

${ }^{65}$ Art. 6.3 SCM was extensively discussed in the US - Upland Cotton Appellate Body Report, WT/DS267/AB/R.

${ }^{66}$ Interestingly, the Appellate Body noted that a de jure export contingency does not require that the instrument used always provides in express terms that the subsidy is available only upon fulfilment of the confition of export performance. See Appellate Body Report, US - FSC (21-5 - EC), WT/DS 108/AB/RW, para. 112.
} 
In Canada - Aircraft, the Appellate Body ruled that the existence of de facto export contingency 'must be inferred from the total configuration of the facts constituting and surrounding the granting of the subsidy, none of which on its own is likely to be decisive in any given case. ${ }^{67}$ To satisfy the standard of de facto export contingency, the Appellate Body suggested that a relationship of conditionality or dependence must be demonstrated between the subsidy and actual or anticipated exportation or export earnings. Thus, the granting of the subsidy must be tied to the anticipation of exportation. ${ }^{68}$ In EC and certain Member States - Large Civil Aircraft, the Appellate Body clarified the legal standard by noting that the factual equivalent of the relationship of conditionality attempts to answer the question as to whether the granting of the subsidy is 'geared to induce the promotion of future export performance by the recipient'. In answering this question, the judiciary has to focus on the subsidy itself rather than the authority's reasons or subjective motivation for the granting of the subsidy. ${ }^{69}$ The Appellate Body went on to emphasize that the standard for export contingency is met when the subsidy is granted so as to provide an incentive to the recipient to export in a way that is not simply reflective of the conditions of supply and demand in the domestic and export markets undistorted by the granting of the subsidy. ${ }^{70}$

Viewed against this backdrop, it appears that no explicit subsidy contingent on export performance was granted, at least in the first two years of the crisis. Nonetheless, as the crisis evolved and the recession grew, protectionist policies reportedly reemerged, ${ }^{71}$ whereas various WTO Members introduced or increased export subsidies. This was the case for instance in the EU with the reintroduction of export refunds for butter, cheese and milk powder, and in the US with the extension of subsidies on dairy products. ${ }^{72}$ WTO-consistent export financing also increased to stimulate trade flows. ${ }^{73}$ For the most part, the rescue and fiscal stimulus measures adopted during the financial crisis, such as tax breaks, preferential interest loans, or investment in failing companies, would qualify as domestic subsidies. Such subsidies are mostly applied in developed countries, as developing countries usually lack financial resources.

\section{The Regulation of Subsidies in the GATS}

When it comes to the regulation of services and governmental intervention, banking, together with transport and tourism, was among the most heavily subsidized services

\footnotetext{
67 See Appellate Body Report, Canada - Aircraft, paras 167, 169. The Appellate Body specified the relevant factors to be evaluated, including the design, structure and modalities of operation of the measure at issue, in EC and certain Member States - Large Civil Aircraft, paras 1046ff.

${ }^{68}$ Ibid, para. 172.

${ }^{69}$ See Appellate Body Report, EC and certain Member States - Large Civil Aircraft, judgment of 18 May 2011, WT/DS316/AB/R, paras 1063-4.

${ }^{70}$ Ibid, para. 1045.

${ }^{71}$ See WTO, TPRB, 'Report to the TPRB from the Director-General on Trade-Related Developments (mid-October 2010 - end-April 2011)’, WT/TPR/OV/W/5, 9 June 2011.

${ }^{72}$ OECD; WTO; UNCTAD, above note 48, p. 23.

${ }^{73} \mathrm{Cf}$ Horlick and Clarke, above note 58, at 861-2.
} 
sectors even before the financial crisis. ${ }^{74}$ As noted earlier, measures adopted as part of rescue schemes during the crisis include: direct money transfers to certain financial institutions, guarantees (sometimes unlimited) on bank liabilities, capital injections or liquidity provision to overcome short-term shortages. Such measures can be regarded as subsidies, as they confer a benefit to the subsidized undertakings, thereby distorting conditions of competition with companies that were not equally subsidized by their governments. This gives an unfair comparative advantage to certain undertakings within the post-crisis economic environment. ${ }^{75}$ In some cases, governmental support does nothing other than provisionally saving a failed undertaking and unduly delaying drawing a much-needed restructuring plan that would establish solid foundations for its long-term viability.

It is precisely this type of distortion to the nature and extent of competition in finance that makes the case for promoting greater coordination of regulatory responses to the crisis beyond the national level a compelling one. It is all the more necessary if one takes into account that national banks and governments have become major shareholders of distressed financial institutions. ${ }^{76}$ These institutions could very well determine the level of financial globalization and interconnectedness in the post-crisis era. For instance, once national shareholders become sellers after a few years, domestic banks may become less internationalized or even exclusively domestically owned if shares end up primarily in the hands of domestic investors. This could reduce the higher levels of financial market internationalization, which prevailed in the years before the financial crisis. Significant distortionary effects on the allocation of capital within and across borders could thus materialize. ${ }^{77}$ Importantly, the intermingling of the state with the financial sector can have repercussions on their lending strategy; for instance, support to financial institutions may be tied to the granting of loans to domestic undertakings and natural persons to revitalize the national economy. Being the input of any commercial activity, any intervention that affects the business strategy of a given financial institution, which is not driven by market considerations, can distort trade, competition and investment. ${ }^{78}$

While state aid schemes displaying traits similar to those just described would in principle be challengeable under the SCM, distortions of competition in services markets are shielded for the most part. This is because the GATS does not contain any explicit subsidy disciplines, but rather a mandate for Members to negotiate the necessary multilateral disciplines with a view to avoiding trade-distortive subsidies in the area of services. ${ }^{79}$ Article $\mathrm{XV}: 2$ merely requires that sympathetic consideration be

\footnotetext{
${ }^{74}$ See WTO, above note 56, pp. 179, 185; also WTO, Working Party on GATS Rules, 'Subsidies for Services Sectors - Information Contained in WTO Trade Policy Reviews', S/WPGR/W/25/Add.5, 27 March 2007.

${ }^{75}$ See WTO, 'Financial Services', above note 4, p. 31.

${ }^{76}$ The US Treasury, for instance, has become a major shareholder in various financial institutions and companies in the wake of the crisis. See OECD; WTO; UNCTAD, above note 48, p. 99ff.

${ }^{77}$ FSB, above note 16.

${ }^{78}$ See also B. De Meester, 'The Global Financial Crisis and Government Support for Banks: What Role for the GATS?' (2010) 13:1 Journal of International Economic Law 27

${ }^{79}$ This mandate is one of the Uruguay Round leftovers, the others being Articles VI para.4; X; and XIII GATS.
} 
given to the request for consultations by a Member that considers itself adversely affected by a subsidy granted by another Member. Negotiations on subsidies within the Working Party on GATS Rules have not made any substantial progress to date. ${ }^{80}$ Several factors, including the four-mode nature of services trade and its impact on defining services subsidies and the special social value of certain services sectors, are to blame for this delay. ${ }^{81}$ The negligible progress in the negotiations arguably reflects a clearly revealed policy preference for regulatory inaction on the part of those WTO Members with the deepest pockets. ${ }^{82}$

This absence of disciplines regulating the provision of subsidies constitutes a major gap in the multilateral framework of services trade regulation and an inexplicable neglect notably on the part of the countries which do not have the means to match such subsidies at the domestic level. Thus, in the absence of legal provisions in the GATS regulating the granting of subsidies, subsidy practices of the type enacted during the financial crisis, which have the potential to distort trade and investment, can proceed with almost full impunity. ${ }^{83}$ This should not be taken to mean that the GATS does not apply to subsidies, which unquestionably constitute 'measures affecting trade in services' within the meaning of Articles I:1 and XXVIII(a) GATS. This would mean that subsidies should in principle comply with the non-discrimination principle enshrined in the GATS. Taking into account the unconditional MFN obligation of Article II GATS, subsidies would have to be included in the list of MFN exemptions of a given Member in order to escape the scope of Article II. ${ }^{84}$ By the same token, pursuant to Article XVII GATS, subsidies cannot be discriminatory unless they are scheduled. ${ }^{85}$ Thus, failure to schedule the right to grant subsidies at a domestic level would mean that a government is required to grant the same subsidies to both domestic and foreign service suppliers, notably when the scheme is available for the entire banking industry and thus the absence of likeness is difficult to prove. However, this latter obligation would only apply to foreign service suppliers that are present in the territory of the subsidizing Member. ${ }^{86}$ It is worth noting at this point that the absence

\footnotetext{
${ }^{80}$ Pietro Poretti, The Regulation of Subsidies within the General Agreement on Trade in Services of the WTO: Problems and Prospects (Alphen aan den Rijn: Kluwer Law International, 2009); also Rudolf Adlung, 'Negotiations on Safeguards and Subsidies in Services: A Never-Ending Story?' (2007) 10 Journal of International Economic Law 235.

${ }^{81}$ Cf. P. Poretti, 'Article XV GATS (Subsidies)' in R. Wolfrum; P.-T. Stoll; and C. Feinäugle (eds), WTO - Trade in Services: Max Planck Commentaries on World Trade Law (Martinus Nijhoff Publishers, 2008), p. 348.

${ }^{82}$ See also P. Delimatsis and P. Sauvé, 'Financial Services Trade After the Crisis: Policy and Legal Conjectures' (2010) 13:3 Journal of International Economic Law 837, at 854.

${ }^{83}$ For the case of export subsidies in services, see WTO, Working Party on GATS Rules, 'Report of the Meeting Held on 1 February 2010', S/WPGR/M/67, 23 April 2010, para. 42.

${ }^{84}$ Again, as the MFN principle refers to discrimination among foreign services or service suppliers, it is unlikely that a WTO Member would violate this obligation, as, for this to occur, it would have to grant the subsidy to one foreign supplier, but not to another foreign supplier of the same service.

${ }^{85}$ See WTO, Trade in Services, 'Guidelines for the Scheduling of Specific Commitments Under the General Agreement on Trade in Services (GATS)', S/L/92, 28 March 2001, para. 16.

${ }^{86}$ Cf. WTO, 'Guidelines for the Scheduling of Specific Commitments under the General Agreement on Trade in Services (GATS), S/L/92, 28 March 2001, paras 15-16. See also the definition of commercial presence in the GATS under Art. XXVIII (d).
} 
of a definition of subsidy does not affect our observations, as long as the GATS has a broad scope ratione materiae, covering any measure affecting trade in services.

Aware of the scope of GATS, several Members have limited eligibility for subsidies to nationals either within specific sectors or across the board, through so-called horizontal limitations. ${ }^{87}$ Therefore, the consistency of the subsidy-like bailout and rescue measures that WTO Members have adopted in recent times can ultimately be assessed after a review of the commitments that any given Member inscribed in its Schedule of Commitments. In addition, the obligations relating to transparency enshrined in Articles III and VI:1 are also applicable to this type of measure, but are also to be read in conjunction with the commitments undertaken by the subsidizing Member.

A factor that renders the success of a complaint against a rescue measure in the financial sector even less likely is the existence of the prudential carve-out enshrined in paragraph 2 of the GATS Annex on Financial Services. ${ }^{88}$ The carve-out recognizes the prerogative of WTO Members to adopt any measure aimed at the protection of investors, consumers of financial services, or of financial stability in general. ${ }^{89}$ In this respect, the carve-out does not prescribe the type of measures that can be adopted, but rather recognizes a relatively high level of discretion as to the prudential measures chosen, depending on domestic regulatory traditions and the market failure to be remedied. The diversity of the WTO membership obliges the GATS to take an objective rather than a design-based approach in this area. Thus, this provision entails a safe harbour for the responding party to justify the violation of any GATS provision.

Be this as it may, the existence of the prudential carve-out by no means affects or diminishes the importance of adopting a services-specific framework regulating the granting of subsidies. Numerous possibilities are available to Members. For instance, there appears to be no compelling reason which would preclude the adoption of an approach that would distinguish among prohibited, actionable and non-actionable subsidies, following the SCM model. A possible framework would also include exceptions to allow the pursuit of legitimate policy objectives. In that sense, broadening the list of Article XIV GATS should be envisaged. Finally, any prospective framework should include a mechanism that would ensure adequate management and monitoring of emergency situations, be it in the area of financial services or any other service sector. In this respect, the framework would have to take into account possible vulnerabilities in the developing world. The ongoing GATS

\footnotetext{
87 See, for instance, WTO, Working Party on GATS Rules, 'Limitiations in Members' Schedules Relating to Subsidies', S/WPGR/W/13/Add.2, 30 August 2004.

${ }^{88}$ Para. 2 of the Financial Services Annex reads:

Notwithstanding any other provisions of the Agreement, a Member shall not be prevented from taking measures for prudential reasons, including for the protection of investors, depositors, policy holders or persons to whom a fiduciary duty is owed by a financial service supplier, or to ensure the integrity and stability of the financial system. Where such measures do not conform with the provisions of the Agreement, they shall not be used as a means of avoiding the Member's commitments or obligations under the Agreement.

${ }^{89}$ See P. Delimatsis, 'Financial Innovation and Prudential Regulation - The Impact of the New Basel III Rules’, 2011, available at: www.ssrn.com.
} 
negotiations on safeguards may prove very useful in creating a coherent framework for this type of situation.

\section{E. Conclusion}

A striking feature of finance revealed by the recent financial crisis has been its intermingling with politics. Politics undoubtedly played an important role in causing the crisis. First, it was political pressure that encouraged exaggerated and imprudent lending to borrowers, which failed to meet the basic criteria of creditworthiness. In the US, for instance, legislative initiatives, at least since the late 1970s, put pressure on banks to provide access to credit to all classes of the population. Second, politics nourished moral hazard, by insinuating that governments would intervene to rescue financial institutions in case of failure, thereby creating a distortive system of incentives and allowing the build-up of leverage. During the crisis, governments were called upon to manage, inter alia, the disastrous effects of their previous behaviour.

Subsidization in every possible form has been the prime instrument used by governments to restore financial stability and confidence as to the solvency of financial institutions. One interesting outcome of the crisis that should be closely followed in the post-crisis landscape is the emergence of new banks, offspring of mergers and takeovers during the crisis. US data suggest that the largest US banks entered the crisis with the lowest capital ratios, but the end of the crisis finds them stronger in terms of capital owing to sometimes unlimited governmental support. The problem of moral hazard was not confronted during this crisis. The largest banks enjoyed the lowest cost of funding, suffered the greatest losses and enjoyed the most governmental subsidization. In the UK, it is estimated that through the higher credit ratings due to perceived governmental support, the five largest UK banks benefited by a total of $£ 55$ billion per year in the period 2007-09 thanks to preferential wholesale funding rates. ${ }^{90}$

As a result of their involvement in restoring financial stability, governments became significant shareholders of various financial institutions in their respective jurisdictions. Of course, it is worth noting that several possibly WTO-inconsistent schemes, facilities or guarantees may not have been used, are no longer valid, or were one-offs. In addition, the extraordinary situations that state intervention caused are slowly disappearing, as the undertakings start returning to the governments the funds that they received or, alternatively, governments sell the stock that they initially obtained. From a WTO perspective, this phenomenon means that the effects of subsidization are about to fade and thus the potential for complaints against certain government practices is limited, taking into account that no retroactive remedies are possible in the WTO.

Finally, an important feature of the restructuring and long-term viability measures that were imposed on undertakings is the abandonment of non-traditional banking

\footnotetext{
${ }^{90}$ See IMF, Global Financial Stability Report: Durable Financial Stability - Getting There from Here, April 2011, p. 54.
} 
activities and exposures to financial innovative products and complex instruments that those undertakings did not understand. The crisis revealed that the trading of previously hailed financial innovative products is a serious matter that can lead to disaster. In the short run, this will most likely lead to a reassessment of the existing financial innovations and the shift of financial institutions towards better tested innovative instruments, in an attempt to minimize risk, while still managing to diversify. It remains to be seen how risk-taking will be regulated and harnessed in the post-crisis environment. While new corporate governance rules are adopted either through the institutions' own initiative or through legislative acts, changing the everyday function and the mindset of bankers will be a challenge for regulators. 